\title{
INCREASING HEAVY OIL RESERVES IN THE WILMINGTON OIL FIELD THROUGH ADVANCED RESERVOIR CHARACTERIZATION AND THERMAL PRODUCTION TECHNOLOGIES
}

Cooperative Agreement No.: DE-FC22-95BC14939

Contractor Names: City of Long Beach Department of Oil Properties (City) and Tidelands Oil Production Company (Tidelands), Long Beach, CA.

Date of Report: December 4, 1995

Award Date: March 30, 1995

Anticipated Completion Date: March 29, 1999

DOE Award: $\$ 4,910,541(1995)$

Principal Investigator:

Scott Hara - Tidelands

Program Manager:

Edith Allison

Bartlesville Project Office

Reporting Period: July 1, 1995 to September 30, 1995

\author{
DISCLAIMER
}

This report was prepared as an account of work sponsored by an agency of the United States Government. Neither the United States Government nor any agency thereof, nor any of their employees, makes any warranty, express or implied, or assumes any legal liability or responsibility for the accuracy, completeness, or usefulness of any information, apparatus, product, or process disclosed, or represents that its use would not infringe privately owned rights. Reference herein to any specific commercial product, process, or service by trade name, trademark, manufacturer, or otherwise does not necessarily constitute or imply its endorsement, recommendation, or favoring by the United States Government or any agency thereof. The views and opinions of authors expressed herein do not necessarily state or reflect those of the United States Government or any agency thereof. 


\section{Objectives}

The project involves improving thermal recovery techniques in a slope and basin clastic (SBC) reservoir in the Wilmington field, Los Angeles Co., Calif. using advanced reservoir characterization and thermal production technologies.

The existing steamflood in the Tar zone of Fault Block II-A has been relatively inefficient because of several producibility problems which are common in SBC reservoirs. Inadequate characterization of the heterogeneous turbidite sands, high permeability thief zones, low gravity oil, and nonuniform distribution of remaining oil have all contributed to poor sweep efficiency, high steam-oil ratios, and early steam breakthrough. Operational problems related to steam breakthrough, high reservoir pressure, and unconsolidated formation sands have caused premature well and downhole equipment failures. In aggregate, these reservoir and operational constraints have resulted in increased operating costs and decreased recoverable reserves. The advanced technologies to be applied include:

(1) Develop three-dimensional (3-D) deterministic and stochastic geologic models.

(2) Develop 3-D deterministic and stochastic thermal reservoir simulation models to aid in reservoir management and subsequent development work.

(3) Develop computerized 3-D visualizations of the geologic and reservoir simulation models to aid in analysis.

(4) Perform detailed study on the geochemical interactions between the steam and the formation rock and fluids.

(5) Pilot steam injection and production via four new horizontal wells (2 producers and 2 injectors).

(6) Hot water alternating steam (WAS) drive pilot in the existing steam drive area to improve thermal efficiency.

(7) Installing an $\mathbf{2 4 0 0}$ foot insulated, subsurface harbor channel crossing to supply steam to an island location.

(8) Test a novel alkaline steam completion technique to control well sanding problems and fluid entry profiles.

(9) Advanced reservoir management through computer-aided access to production and geologic data to integrate reservoir characterization, engineering, monitoring, and evaluation.

\section{Summary of Technical Progress}

This is the second quarterly technical progress report for the project. Although the contract was awarded on March 30, 1995 and Pre-Award Approval was given on January 26, 1995, work was initiated on October 1, 1994. As such, this report summarizes the work performed from project inception to September 30, 1995. 
Significant progress was made during the quarter. Three observation wells and two core hole/observation wells were drilled to monitor steam drive operations, a $2400 \mathrm{ft}$ steam line was installed under the Cerritos Channel to provide steam to an island location, and the drilling of four horizontal wells (two producers and two steam injectors) and installation of well facilities were essentially on schedule with startup of steam injection projected for mid-December 1995. Work was started on the basic reservoir engineering and a working deterministic geologic model was completed which allowed work to commence on the stochastic geologic and reservoir models.

Regarding technical transfer, several papers are being prepared for the 1996 Annual American Association of Petroleum Geologists Convention in April. Several project team members are significantly involved in the planning of this convention as well as the 1997 Society of Petroleum Engineers Western Regional Meeting. A home page was created on the Internet (http://spidey.usc.edu/ yusuf/pet.html) for the project.

\section{- Compilation and Analysis of Existing Data}

A computer database of production and injection data, reservoir engineering data, and digitized and normalized log data was completed sufficiently to start work on the basic reservoir engineering and geologic stochastic model. Quality control checks on the production and injection database should be completed by late October. Logs from 126 wells have been digitized and logs from another 45 wells should be completed by late December. The digitized logs include the electric or induction and the spontaneous potential (SP) and/or gamma ray (GR). The 171 wells (of over 600 wells penetrating the Tar zone in the area) are distributed throughout the fault block. The logs were normalized and environmentally corrected for 71 wells and the remaining logs are to be corrected in 10 well increments as needed.

\section{- Advanced Reservoir Characterization}

Basic reservoir engineering proceeding with analysis of primary and waterflood recoveries and material balance. Permeability estimates from performance data have been completed. Work is continuing on evaluating the acquifer, comparing water injection profile surveys to the allocated injection volumes to each sub-zone, determining the quality of the new and old well logs, and performing correlation studies on projected steam drive recoveries from vertical and horizontal wells.

Started drilling four horizontal wells in mid-September using measurement while drilling (MWD) and logging while drilling (LWD) to direct the course of the wells. Initial indications are that the LWD provides correlatable resistivity measurements when compared to the recently drilled observation wells. The sub-zone sands appear to be continuous going east to west across the fault block. 
Lab work proceeding to identify non-radioactive reservoir tracers effective in high temperature $\left(600^{\circ} \mathrm{F}\right)$ environments. Locating cost effective tracers harder than anticipated so criteria eased to locate tracers at $500^{\circ} \mathrm{F}$ by mid-December. Tracer injection slated to begin in mid-January 1996.

Drilled three observation wells and two core hole/observation wells. Good quality logs (Induction/SP/GR/density/neutron/electromagnetic propagation tool (EPT)) were retrieved except for the EPT. A repeat formation tester (RFT) was run in observation well OB 2-1 which showed that the reservoir pressures within the D1 sub-zone were in vertical hydrostatic pressure communication and were different from the sub-zones directly above and below. The D1 sub-zone is the steam drive interval for the horizontal wells. Core recovery through the $T$ and $D$ sub-zones was excellent as over $99 \%$ of the planned core interval of $517 \mathrm{ft}$ was recovered. The plan is to perform conventional porosity, permeability, and oil saturation measurements on core plugs. A proposal is being developed on high temperature core work to determine residual oil saturations to different steam temperatures, to determine formation rock and fluid alterations caused by different steam temperatures, and to determine the physical phenomena behind the successful perforated well completions in unconsolidated sands when initially stimulated with steam.

A working deterministic 3-D geologic model was completed which was sufficient to start work on the stochastic 3-D geologic model and to use for drilling the observation and horizontal wells. A flaw in the geologic database software was discovered during drilling of the observation wells that caused the geologic structure maps to be off by as much as 17 feet in Fault Block II. The geologic database software normalizes the historic well survey and log data for the different surface coordinate systems employed in the field and for surface subsidence. The subsidence module was faulty, but was fixed enough to reduce the error to less than two feet before the horizontal wells were drilled. Refinements to the deterministic model such as re-evaluating the fault picks should be completed in the First Qtr 1996. All existing core data was visually inspected in order to develop a core-based log model. The model will incorporate the two new cored wells and will be completed in the First Qtr 1996. The core-based log model will be used for developing the porosity-permeability model and rock-log model.

Other deterministic geologic studies underway include the barrier characteristics of the geologic faults and correlating the stratigraphic characteristics of the Tar zone with similar deposits in neighboring fields.

On the stochastic geologic model, a neural network analyzer has been developed to analyze the similarities of various zones and sub-zones in terms of sequence stratigraphy using GR logs.

- Reservoir Simulation 
The evaluation to select a thermal reservoir simulator program is continuing. Goal is to select and negotiate terms for a specific software package by the end of December and have simulator and computer onsite by February 1.

\section{- Reservoir Management}

Completed planning and programming of the four proposed horizontal wells (two injectors and two producers). Final bottom-hole targets revised based on new log data from observation wells and corrections to geologic database. Started drilling in early September and anticipate finishing by late October. Plan to start completing wells in late November and initiating steam injection in mid-December. The associated well facilities will be installed in time to meet the planned well start-up. The plan is to perform a $100,000 \mathrm{bbl}$ steam cycle on each well to consolidate the formation sands around the perforated completions and to stimulate initial production.

The $2400 \mathrm{ft}$ steam transmission line under the Cerritos Channel was completed during the quarter. The transmission line included a 42 in. bore under the channel, a $30 \mathrm{in}$. outer line which was pulled through the bore and cemented in place, and dual concentric lines consisting of a 14 in. insulated steam line inserted inside a 24 in. backup line which were pulled through the 30 in. line together. Tie-in of associated surface lines are on schedule to meet the planned well start-up date.

Four existing steam injection wells were converted to hot water injection in March, 1995. Injection rates were increased from a total of 800 barrels of cold water equivalent steam per day (BCWESPD) last quarter to 3000 BCWESPD during this quarter. No production response to date.

Detailed thin section, scanning electron microscope, and $\mathrm{x}$-ray diffraction work on wellbore fill samples from the existing steam drive wells show several types of scale including calcites, dolomites, barites, anhydrites, and magnesium-silicates. Cores, produced fluids, and injection water will be examined to determine the mineralogy and source of the scales and how to prevent their occurrence. Design of high temperature lab work on the cores is proceeding and should be completed in December. Actual high temperature lab work on the cores is scheduled to begin in January 1996.

The horizontal steam drive wells will be operated based on a pseudo "steam assisted gravity drainage (SAGD)" technique. The SAGD technique was designed by Butler $r^{1,2}$ and has been tested extensively in the heavy oil fields in Canada. Several articles have been written on the SAGD technique in the Canadian Journal of Petroleum Technology. A good article summarizing the heavy oil recovery techniques used in Canada was written by Polikar and Redford ${ }^{3}$. The pseudo SAGD method to be employed involves completing the last $600 \mathrm{ft}$ of the horizontal wells in the most updip section of the reservoir. The horizontal segments of the wells average $1300 \mathrm{ft}$ and were drilled going west to east at a $96-99^{\circ}$ angle (going uphill) to compensate 
for the reservoir dip. The concept is to concentrate the steam updip in a smaller area to take advantage of gravity segregation of the steam in order to promote earlier development of a steam chest. As the steam chest grows to envelop the producer completion intervals, more perforations will be opened downdip and the updip perforations will be plugged off, if necessary. The pseudo SAGD technique is preferred over a conventional SAGD technique because the Tar zone has more mobile oil (13 $3^{\circ} \mathrm{API}$ gravity) than the bitumen in Canada and has very mobile free water located primarily downdip and along the bottom of the sands caused by prior waterflooding.

\section{- Operational Management}

Most of this work is dependent upon the results of the high temperature core work to be performed. A cyclic steam sand consolidation treatment was performed on an existing steam drive well (Well No. UP-932) to fix a bad slotted liner completion with running sand. The alternative was to install an expensive inner slotted liner with a gravel pack. Production results over a one year period showed that sand production was successfully eliminated and the production rates were stabilized at 32 barrels of oil per day and 400 barrels of gross fluid production per day, both rates being down about $20 \%$ from previous rates before the well experienced sanding problems. Despite the production decline, this sand consolidation treatment was considered successful since inner slotted liner completions generally experience the same production rate declines.

\section{References}

1. Butler, R. M.: Horizontal Wells for the Recovery of Oil, Gas and Vitumen; Monograph 2, Petroleum Society of CIM, Calgary 1994

2. Butler, R. M.: Gravity Drainage to Horizontal Wells; Journal of Canadian Petroleum Technology, Volume 31, No. 4, pp. 31-37, April 1992

3. Polikar, M. and Redford, D. A.: Evolution of Steam-based Technology for the Recovery of Canadian Heavy Oil Reservoirs; Journal of Canadian Petroleum Technology, Volume 34, No. 5, pp. 33-40, May 1995 